\title{
Penalaran Statistis Siswa dalam Menyelesaikan Masalah Case Study
}

\author{
Baiq R. A. Febrilia
}

\author{
Pendidikan Matematika, IKIP Mataram \\ Jalan Pemuda No. 59A, Mataram, Nusa Tenggara Barat, Indonesia \\ rika.febrilia@gmail.com
}

Artikel diterima: 15-02-2019, direvisi: 26-05-2019, diterbitkan: 31-05-2019

\begin{abstract}
Abstrak
Penalaran siswa secara statistika belum begitu baik, kebanyakan siswa menggunakan terminologi yang tidak sesuai dengan maksud dari terminologi yang seharusnya. Penelitian ini bertujuan untuk mendapatkan gambaran mengenai penalaran statistis melalui permasalahan case study. Jenis penelitian ini adalah deskriptif kualitatif dan melibatkan 9 orang mahasiswa Program Studi Pendidikan Matematika, di mana 3 diantaranya berjenis kelamin laki-laki dan yang lainnya adalah perempuan. Instrumen yang digunakan berupa permasalahan case study yang relevan dengan permasalahan nyata di dunia dengan fokus materi pada hal-hal yang berhubungan dengan konsep dasar statistika dan bentuk penyajian data. Hasil penelitian menunjukkan bahwa hampir sebagian besar subjek memiliki kemampuan penalaran statistis pada level penalaran idiosinkratik dan penalaran verbal berkaitan dengan konsep tertentu sedangkan level prosedural dan pengintegrasian proses muncul pada permasalahan terkait bentuk penyajian data. Agar level penalaran statistis siswa dapat meningkat, maka diperlukan adanya rancangan permasalahan yang tepat.

Kata Kunci: penalaran statistis, deskriptif kualitatif, masalah case study.
\end{abstract}

\section{Students' Statistical Reasoning in Solving Case Study Problem}

\begin{abstract}
Student reasoning is statistically not so good; most students use terminology that is not by following the intended meaning of the terminology. This study aims to get an overview of statistical reasoning through a case study problem. This type of research is descriptive qualitative and involves 9 students of the Mathematics Education Department, which 3 are male and the others are female. The instrument used is a case study problem that is relevant to real problems in the world with a focus on material on the basic concepts of statistics and forms of data presentation. The results showed that most subjects had statistical reasoning abilities at the level of idiosyncratic reasoning and verbal reasoning was related to certain concepts, while procedural levels and process integration appeared on problems related to the form of data presentation. So that the level of students' statistical reasoning can increase, it is necessary to design appropriate problems.

Keywords: statistical reasoning, descriptive qualitative, case study problem.
\end{abstract}




\section{Pendahuluan}

Statistika telah banyak digunakan dalam membantu permasalahan di bidang ilmu lain seperti pertanian, farmasi, dirgantara, ekonomi dan teknik termasuk pada perusahaan-perusahaan di dunia untuk mendapatkan teknologi terbaik dan menganalisis permasalahan tertentu (Ulpah, 2009). Dengan memahami statistika, seseorang dapat menganalisis dan memprediksi kuantitas produksi tebu, gula (Apriawan, Irham, \& Mulyo, 2014) dan curah hujan (Mirawati, Yasin, \& Rusgiyono, 2013; Tresnawati, Nuraini, \& Hanggoro, 2010), mengendalikan kualitas produksi (Ratnadi dan Suprianto, 2018) dan melakukan analisa faktor-faktor yang mempengaruhi keinginan membeli suatu produk dalam rangka memberikan kepuasan pelanggan (Lestiani, 2018).

Kemampuan penalaran statistis merupakan salah satu kompetensi yang dibutuhkan oleh seorang siswa mengingat begitu banyaknya kegunaan statistika dalam kehidupan sehari-hari (Ulpah \& Kusumah, 2012). Kemampuan penalaran statistis merupakan kemampuan yang dimiliki siswa dalam memahami berbagai informasi yang dapat mereka temukan di dalam keseharian mereka, termasuk juga kemampuan siswa dalam mengumpulkan, mengolah, menyajikan, mereduksi, menyimpulkan dan mempresentasikan data (Maryati, 2017).

Garfield (2002) menjelaskan mengenai beberapa aspek dalam statistika yang dapat digunakan untuk mengembangkan

kemampuan penalaran siswa, yaitu (a) Penalaran mengenai data, seperti mengenali atau mengkategorikan data sebagai data kualitatif atau kuantitatif, diskrit atau kontinu dan syarat dari suatu data yang dapat disajikan dalam beberapa bentuk penyajian data, (b) Penalaran mengenai representasi dari data, seperti memahami bagaimana grafik dapat dimodifikasi untuk mewakili kumpulan data dengan lebih baik, (c) Penalaran mengenai ukuran statistika, seperti mengetahui ukuran mana yang digunakan untuk data yang dimiliki, (d) Penalaran mengenai ketidakpastian, seperti menggunakan dengan benar ide mengenai peluang, keacakan, kemungkinan dari suatu kejadian, (e) Penalaran mengenai sampel, seperti mengetahui bagaimana sampel terkait dengan suatu populasi dan (f) Penalaran mengenai hubungan, seperti mengetahui bagaimana cara menjustifikasi dan merepresentasikan hubungan antara dua buah variable. Sedangkan level penalaran statistis siswa dapat diukur melalui model yang juga dikembangkan oleh Garfield (2002) seperti yang ditunjukkan pada tabel 1.

Beberapa penelitian menyebutkan bahwa penalaran siswa secara statistika belum begitu baik. Kebanyakan siswa menggunakan terminologi yang tidak sesuai dengan maksud dari terminologi tersebut, menghafal rumus-rumus dan prosedur atau langkah-langkah yang diberikan tanpa memahami konsep terlebih dahulu, sehingga memunculkan ketidaksiapan dan kebingungan dalam diri 
siswa saat mengerjakan soal yang dirancang sedikit berbeda dengan yang biasa dikerjakan (Setyorini, Pramudya, \& Setiawan, 2017). Ketika siswa diminta untuk membaca data dalam grafik, seperti scatter plot, sebenarnya siswa diminta untuk menjelaskan pelabelan dari plot tersebut, menginterpretasikan skala atau menemukan nilai koordinat dari satu titik atau titik yang lain (Batanero, Godino, Vallecillos, Green, \& Holmes, 1994).

Untuk meningkatkan penalaran statistis siswa, guru perlu memberikan pemahaman kepada siswa mengenai berbagai macam arti penting dan manfaat dalam mempelajari statistika, guru perlu merancang aktivitas, tugas atau permasalahan yang diharapkan dapat membawa siswa kepada pemahaman yang lebih mendalam mengenai statistika. Febrilia (2017) memberikan salah satu aktivitas alternatif dalam mengintegrasikan teori statistika. Hasil penelitiannya menunjukkan bahwa dengan adanya integrasi antara teori dan praktek lapangan, mahasiswa lebih memaknai teori yang telah diajarkan di kelas dan dengan demikian pemahaman statistika yang mereka miliki juga semakin baik.

Prabowo (2012) juga memberikan alternatif aktivitas dalam merancang pembelajaran berbasis proyek yang mampu meningkatkan pemahaman siswa dalam kegiatan pengumpulan, pengolahan dan analisis data, sedangkan Rahman (2018) menerapkan pendekatan Realistic Mathematic Education (RME) dalam meningkatkan pemahaman statistika siswa. Secara lebih khusus, hasil penelitian Maryati (2017) menyebutkan bahwa kemampuan penalaran statistis siswa dapat ditingkatkan melalui pembelajaran kontekstual, sedangkan hasil penelitian Nisa, Zulkardi, dan Susanti (2019) menyatakan bahwa penalaran statistis siswa melalui pembelajaran PMRI berada

Tabel 1.

Jenis Penalaran Statistis

\begin{tabular}{ll|}
\hline \multicolumn{1}{c}{ Jenis Penalaran } & \multicolumn{1}{c}{ Indikator } \\
\hline Penalaran Idiosinkratik & $\begin{array}{l}\text { Siswa mengetahui beberapa istilah dan simbol dalam statistika. } \\
\text { Siswa menggunakan istilah dan simbol tanpa memahami maksud dari } \\
\text { istilah dan simbol tersebut sepenuhnya. } \\
\text { Siswa salah memahami atau menukar maksud dari istilah dan symbol yang } \\
\text { digunakan. }\end{array}$ \\
\hline Penalaran Verbal & $\begin{array}{l}\text { Siswa memahami secara verbal beberapa konsep dalam statistika, namun } \\
\text { belum bisa menerapkan konsep tersebut dalam permasalahan nyata. }\end{array}$ \\
\hline Penalaran Transisional & $\begin{array}{l}\text { Siswa mampu mengidentifikasi hubungan dari satu atau dua dimensi dari } \\
\text { suatu proses statistika dengan benar tanpa melakukan integrasi terhadap } \\
\text { beberapa dimensi ini. }\end{array}$ \\
\hline Penalaran & $\begin{array}{l}\text { Siswa dapat mengidentifikasi suatu konsep atau proses statistika dengan } \\
\text { benar, namun belum bisa memahami prosesnya atau tidak dapat } \\
\text { mengintegrasikannya. }\end{array}$ \\
\hline mentegrasian Proses & $\begin{array}{l}\text { Siswa memahami dengan baik mengenai proses statistika dan mampu } \\
\text { menjelaskan proses statistika dengan menggunakan kata-katanya sendiri. }\end{array}$ \\
\hline
\end{tabular}


pada kategori baik.

Selain rancangan aktivitas, rancangan juga mempengaruhi tingkat penalaran statistis siswa (Manfaat \& Nurhairiyah, 2013). Tugas atau permasalahan yang siswa kerjakan juga akan mempengaruhi cara pandang mereka terhadap suatu permasalahan. Salah satu tugas atau permasalahan yang dianggap mampu untuk meningkatkan penalaran statistis siswa adalah tugas berbentuk case study (Garfield \& Chance, 2000). Permasalahan dalam bentuk case study dianggap mampu untuk meningkatkan kemampuan penalaran statistis siswa karena rincian masalahnya merupakan suatu konteks yang nyata dan dapat mendorong siswa untuk memberikan strategi dan interpretasi yang dapat digunakan untuk memecahkan masalah.

Beberapa penelitian terdahulu telah menerapkan case study sebagai bagian penting dari penelitiannya. Kesulitan siswa dalam menganalisis soal-soal kemampuan pemecahan masalah dapat teratasi melalui pemberian masalah yang nyata (Sholihah \& Afriansyah, 2017). Selain itu, analisa kesalahan penggunaan konsep pecahan dilakukan melalui pemberian soal (Yulianingsih, Febrian, \& Dwinata, 2018). Di level universitas, Ekayanti (2017) mendiagnosis kesalahan mahasiswa dalam permasalahan pembuktian, soal telah dikondisikan supaya mahasiswa berperan aktif dalam memecahkan masalah tersebut. tugas atau permasalahan di dalam kelas

Berdasarkan uraian di atas, maka dianggap penting untuk mengetahui bagaimana penalaran statistis siswa melalui masalah case study yang diberikan. Harapannya, hasil ini dapat dijadikan referensi bagi guru dan dosen dalam memberikan alternatif tugas kepada siswa, sehingga siswa dapat memahami secara lebih mendalam mengenai konten yang sedang dan telah diajarkan.

\section{Metode}

Jenis penelitian ini adalah penelitian deskriptif kualitatif yang dimaksudkan untuk memperoleh gambaran mengenai pemahaman statistika siswa secara lebih rinci. Subjek yang terlibat dalam penelitian ini adalah 9 orang mahasiswa tahun kedua Program Studi Pendidikan Matematika, dimana 3 diantaranya laki-laki dan 6 lainnya perempuan. Mahasiswa ini merupakan mahasiswa yang sedang menempuh mata kuliah Statistika Dasar. Masalah case study diberikan di akhir pembahasan suatu bab setelah mahasiswa memperoleh materi tertentu untuk melihat sejauh mana penalaran statistis mereka.

Dalam rangka mengetahui gambaran penalaran statistis siswa, peneliti menggunakan instrumen berupa 2 permasalahan case study yang dikembangkan oleh Weiss (2011). Fokus materi statistika dari penelitian ini adalah mengenai dasar-dasar dalam statistika (seperti istilah-istilah dan konsep dasar statistika) dan statistika deskriptif. Permasalahan pertama terkait dengan 
pemahaman siswa mengenai sampel, diberikan dan bagaimana gambaran populasi, statistika deskriptif dan penalaran statistis siswa berdasarkan inferensial, sedangkan permasalahan jawaban yang siswa berikan atas kedua terkait dengan pemahaman siswa permasalahan tersebut.

mengenai variabel, data dan cara mengorganisir data. Permasalahan ini dipilih karena merupakan studi kasus klasik yang menyoroti relevansi materi dengan permasalahan pada dunia nyata dan merupakan salah satu alat untuk menilai dan mengevaluasi level penalaran statistis siswa (Garfield \& Chance, 2000). Alat analisis yang digunakan adalah kerangka kerja yang dikembangkan oleh Garfield (2002) yang ditunjukkan pada Tabel 1.

\section{Hasil dan Pembahasan}

Penelitian berlangsung selama satu semester. Sebelum diminta untuk mengerjakan permasalahan, subjek diberikan materi dan beberapa latihan soal bagaimana selayaknya perkuliahan normal berjalan. Baru kemudian di akhir pembahasan materi mereka diberikan permasalahan case study. Subjek diminta untuk mengerjakan permasalahan ini di rumah masing-masing dengan maksud agar mereka dapat lebih leluasa dalam mengerjakannya.

Bagian ini membahas secara singkat

\section{A. Permasalahan Case Study}

Permasalahan case study yang digunakan sebagai instrumen tetap diberikan dalam bentuk bahasa inggris agar tidak mengurangi makna aslinya, tetapi sebelum dikerjakan oleh subjek, peneliti terlebih dahulu menjelaskan makna dan maksud dari permasalahan tersebut secara rinci dalam bahasa Indonesia.

Permasalahan pertama yang diberikan kepada siswa berupa narasi yang berkaitan dengan permasalahan mengenai survei untuk menentukan The Greatest American Screen Legend yang dilakukan oleh American Film Institute (AFI). Selain narasi, permasalahan ini juga menyajikan hasil polling berupa 25 besar American Screen Legend pria dan 25 besar American Screen Legend wanita. Permasalahan ini kemudian diikuti dengan daftar pertanyaan yang berkaitan dengan populasi, sampel dan istilah statistika deskriptif atau inferensial seperti pada gambar 1 .

mengenai konteks permasalahan yang 


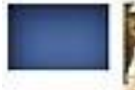

At the beginning of this chapter, we discussed the results of a survey by the American Film Institute (AFI). Now that you have learned some of the basic terminology of statistics, we want you to examine that survey in greater detail.

Answer each of the following questions pertaining to the survey. In doing so, you may want to reread the description of the survey given on page 2 .

a. Identify the population.

b. Identify the sample.

c. Is the sample representative of the population of all U.S. moviegoers? Explain your answer. d. Consider the following statement: "Among the 1800 artists, historians, critics, and other cultural dignitaries polled by AFl, the top-ranking male and female American screen legends were Humphrey Bogart and Katharine Hepburn." Is this statement descriptive or inferential? Explain your answer.

e. Suppose that the statement in part (d) is changed to: "Based on the AFI poll, Humphrey Bogart and Katharine Hepburn are the top-ranking male and female American screen legends among all artists, historians, critics, and other cultural dignitaries." Is this statement descriptive or inferential? Explain your answer.

Gambar 1. Permasalahan Case study 1

\section{P CASE STUDY DISCUSSION \\ 25 HIGHEST PAID WOMEN}

Recall that, each year, Fortone Magazine presents rankings of America's leading businesswomen, including lists of the most powerful, highest paid, youngest, and "movers." On page 35, we displayed a table showing Fortune's list of the 25 highest paid women.

at. For each of the four columns of the table, classify the data as either qualitative or quantitative; if quantitative. further elassify it as diserele or continuous, Also identify the variable under consideration in each case.

l. Use cutpoint grouping to organize the compensation data into frequency and relative-frequency distributions. Use a class width of 5 and a first cutpoint of 5 .

c. Construct frequency and relative-frequency histograms of the compensation data based on your grouping in part (b).

\section{Gambar 2. Permasalahan Case study 2}

Permasalahan kedua juga memiliki redaksional dalam bentuk narasi mengenai 25 Highest Paid Women. Permasalahan ini juga menyajikan data berupa daftar nama 25 wanita karir disertai dengan nama perusahaan dan besar kompensasinya. Daftar pertanyaan yang pada permasalahan 2 berkaitan dengan jenis data dan variabel serta bentuk penyajian yang mungkin dari data tersebut (lihat gambar 2). Kedua permasalahan yang disajikan dilengkapi oleh semua data yang dibutuhkan untuk menjawab soal. d. Identify and interpret the shape of your histograms in part (c).

c. Truncate each compensation to a whole number (i.e., find the greatest integer in each compensation), and then obtain a stem-and-leaf diagram of the resulting data, using two lines per stem.

f. Round each compensation to a whole number, and then obtain a stem-and-leaf diagram of the resulting data, using two lines per stem.

g. Which of the stem-and-leaf diagrams in parts (e) and (f) corresponds to the frequency histogram in part (c)? Can you explain why?

b. Round each compensation to a whole number, and then obtain a dotplot of the resulting data.

\section{B. Penalaran Statistis}

Melalui hasil analisis pada lembar jawaban permasalahan pertama diketahui bahwa kemampuan penalaran statistis subjek hanya berada pada level penalaran idiosinkratik dan penalaran verbal. Untuk pertanyaan bagian a dan $b$, hasil analisis menunjukkan bahwa subjek mampu menggunakan istilah populasi dan sampel serta mengerti bahwa sampel merupakan bagian dari populasi. Akan tetapi, subjek masih kesulitan dalam mengidentifikasi yang mana sampel dan yang mana populasi dari kasus yang diberikan. Hal ini 
bisa saja dikarenakan konsep mengenai sampel dan populasi belum begitu mereka pahami secara utuh (Maryati, 2017). Dari 9 subjek hanya ada 2 subjek yang mampu mengidentifikasi dengan benar mengenai populasi dari kasus tersebut. Dua subjek jawabannya paling mendekati benar dalam mengidentifikasi sampel (lihat gambar 3).

Dalam menjelaskan apakah sampel yang dipilih cukup representatif atau tidak (bagian c), beberapa subjek cenderung menjelaskan terkait dengan alasan yang bersifat tidak ilmiah, seperti "dengan adanya sampel penonton bisa menikmati peran apa yang dibawakan oleh pemain". Pernyataan ini jelas tidak ada hubungannya dengan pertanyaan yang diajukan dalam case study.

Alasan lainnya adalah karena sampel sudah cukup mewakili masing-masing kategori gender dan sudah termasuk penonton dari bioskop AS. Dari sini, kita mendapatkan informasi bahwa subjek belum cukup memahami bagaimana kriteria sampel yang baik dan yang mampu mewakili karakteristik dari populasinya. Level penalaran statistis subjek terkait konsep ini adalah pada level penalaran idiosinkratik.

Soal bagian d dan e, subjek diminta untuk menentukan apakah kalimat dalam soal termasuk statistika deskriptif atau

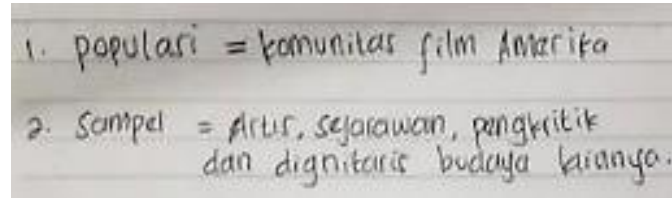

Gambar 3. Jawaban subjek mengenai sampel dan populasi statistika inferensial. Hasil analisis lembar jawaban menunjukkan bahwa beberapa subjek masih belum cukup mengerti dengan konsep statistika deskriptif dan statistika inferensial. Pada kasus ini, penalaran statistis subjek berada pada level penalaran idiosinkratik, dimana subjek mengetahui istilah statistika namun belum memahaminya secara akurat dan pernyataan yang diberikan tidak relevan (Yusuf, 2017; Garfield, 2002).

Beberapa subjek lainnya menunjukkan bahwa mereka mengerti dan mampu menjelaskan hanya satu atau dua kata kunci dari istilah tersebut, namun belum dapat membuat kalimat yang tepat untuk menjelaskan alasan mereka. Dua subjek mampu menjelaskan dengan baik definisi dari statistika deskriptif dan statistika inferensial (lihat gambar 4). Oleh karena mereka mampu menjelaskan dengan baik mengenai konsep tersebut dan mampu pula dalam menggunakan konsep tersebut, maka level penalaran statistis subjek adalah pada level penalaran verbal (Yusuf, 2017; Garfield 2002).

Ringkasan mengenai kemampuan penalaran subjek dalam permasalahan 1 dapat dilihat pada tabel 2. Tabel 2 menunjukkan bahwa level penalaran statistis yang paling tinggi dapat muncul adalah penalaran verbal. Hal ini karena

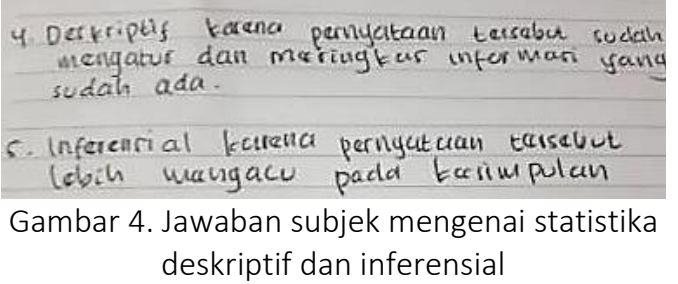


soal-soal pada permasalahan 1 lebih menyangkut pada kemampuan siswa dalam memahami beberapa istilah atau konsep dasar dalam statistika.

Permasalahan kedua memiliki tingkatan materi yang lebih tinggi dibandingkan permasalahan pertama. Pada permasalahan ini yang menjadi penekanan adalah kemampuan subjek dalam menyelesaikan permasalahan yang sifatnya lebih prosedural.

Pertanyaan pertama (bagian a) meminta subjek untuk mengidentifikasi jenis data dan variabel dari beberapa variabel yang disajikan dalam tabel. Subjek juga diminta untuk menjelaskan alasannya. Hasil analisis menunjukkan bahwa subjek mampu memberikan justifikasi jenis data dan variabel yang ada, namun saat menjelaskan alasannya subjek memiliki kesulitan dalam menata kalimatnya (lihat gambar 5). Dengan kata lain, penjelasan subjek masih belum tepat.

Bahkan beberapa subjek malah memilih untuk tidak menjelaskan alasannya. Gambar 6 menunjukkan bahwa subjek hanya mampu menyebutkan jenis data tanpa memberikan alasan. Oleh karena subjek mampu mendefinisikan konsep variabel, namun mereka tidak mampu

Tabel 2.

Penalaran Statistis pada Permasalahan 1

\begin{tabular}{lccccc}
\hline Jenis Penalaran & A & b & c & d & E \\
\hline Penalaran Idiosinkratik & - & - & V & V & V \\
\hline Penalaran Verbal & V & V & V & V & V \\
\hline Penalaran Transisional & - & - & - & - & - \\
\hline Penalaran Prosedural & - & - & - & - & - \\
\hline Penalaran & - & - & - & - & - \\
Pengintegrasian Proses & & & & &
\end{tabular}

menjelaskan dengan baik mengapa suatu variabel dapat dikelompokkan ke dalam kelompok variabel tertentu, maka dapat disimpulkan bahwa level penalaran subjek masih berada pada level penalaran verbal (Maryati, 2017).

Dalam menyajikan data, subjek cukup berhasil menggunakan beberapa teknik penyajian data ada, seperti penyajian dalam bentuk tabel cut-point grouping, histogram, steam and leaf plot dan dot plot (bagian b, c e, f dan h). Gambar 6 berikut merupakan contoh penyajian data dalam bentuk tabel dengan menggunakan cut-point grouping (lihat gambar 7). Tabel penyajian data yang dibuat subjek terdiri atas 4 kolom, di mana kolom pertama merupakan kolom nomor, kolom kedua merupakan kolom pengelompokkan, kolom ketiga frekuensi dan kolom keempat frekuensi relatif. Penyajian dalam bentuk ini menyatakan data menjadi beberapa kelas interval, dimana batas atas intervalnya menggunakan istilah "under (kurang dari) ...". Melalui hasil analisis lembar jawaban subjek, diperoleh informasi bahwa subjek sudah mampu

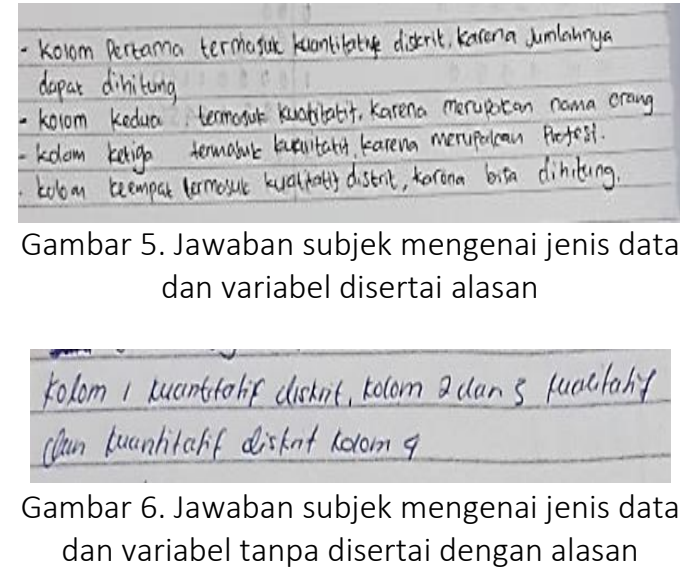

Mosharafa: Jurnal Pendidikan Matematika Volume 8, Nomor 2, Mei 2019 Copyright $\odot 2019$ Mosharafa: Jurnal Pendidikan Matematika 
membuat grup dari data yang diberikan, menghitung frekuensi dan frekuensi relatif dari masing-masing grup tersebut. Dengan demikian, penalaran statistis subjek berada pada level penalaran prosedural.

Hasil tabel dalam gambar 7 kemudian menjadi dasar untuk membentuk histogram pada gambar 8. Dua histogram yang menggunakan frekuensi pada sumbu $y$ nya menunjukkan pemilihan skala yang berbeda. Hal ini menyebabkan lebar histogram dari kedua cara tersebut menjadi berbeda. Meskipun demikian, subjek tetap dikatakan sudah cukup mampu untuk membuat histogram dari data yang diberikan. Penalaran statistis subjek dalam kasus ini telah sampai pada penalaran prosedural.

Contoh hasil penyajian data lainnya yang menunjukkan penalaran statistis subjek pada level prosedural (lihat gambar 9). Pada bagian $d$, subjek diminta untuk memberikan pendapat mereka terkait bentuk distribusi dari data berdasarkan histogram yang telah dibentuk. Hasil

\begin{tabular}{|c|c|c|c|}
\hline \multicolumn{3}{|c|}{ gunakan Data Cutpoin grouping } & 1 \\
\hline NO & cetepoins & Frekuensi. & Frekuens relatit \\
\hline 1. & 5 - under 10 & 5 & 0.2 \\
\hline 2. & 10 - under 15 & 15 & 0,6 \\
\hline 3. & $15-$ Under 20 & 3 & 0,12 \\
\hline 4 . & 20 - Under 25 & 0 & 0 \\
\hline 5. & 25 - Under 30 & 0 & $0 \quad 0$ \\
\hline 6. & $30-$ under 55 & 1 & 0,04 \\
\hline \multirow[t]{2}{*}{7.} & 35 - under 40 & 1 & 0,04 \\
\hline & . & 25 & \\
\hline \multicolumn{2}{|c|}{ gumlats as (uikon $\$$ ) } & frequenfi & frequens relatf \\
\hline \multicolumn{2}{|c|}{$5-210$} & 2 & 5/25 \\
\hline & 15 & $15 / 25$ \\
\hline $15-<20$ & & 3 & $3 / 25$ \\
\hline \multirow{2}{*}{\multicolumn{2}{|c|}{$\begin{array}{l}20-<25 \\
25-<30\end{array}$}} & 0 & - \\
\hline & $-\angle 30$ & 0 & - \\
\hline \multicolumn{2}{|c|}{$30-<35$} & $i$ & 1/er \\
\hline \multicolumn{2}{|c|}{$55-\angle 40$} & 1 & $1 / 4$ \\
\hline
\end{tabular}

Gambar 7. Jawaban subjek mengenai penyajian data dalam bentuk tabel cut-point grouping analisis jawaban subjek menunjukkan masih adanya variasi bentuk distribusi data.

Subjek menganggap bentuk distribusi data tersebut adalah multimodal karena pada batang pertama dan kedua (lihat gambar 8) frekuensi kelompok 1 dan 2 mengalami kenaikan, sedangkan dari batang kedua ke batang ketiga frekuensi mengalami penurunan. Bagian kosong diantara batang ketiga ke batang keempat dipandang sebagai data yang frekuensinya

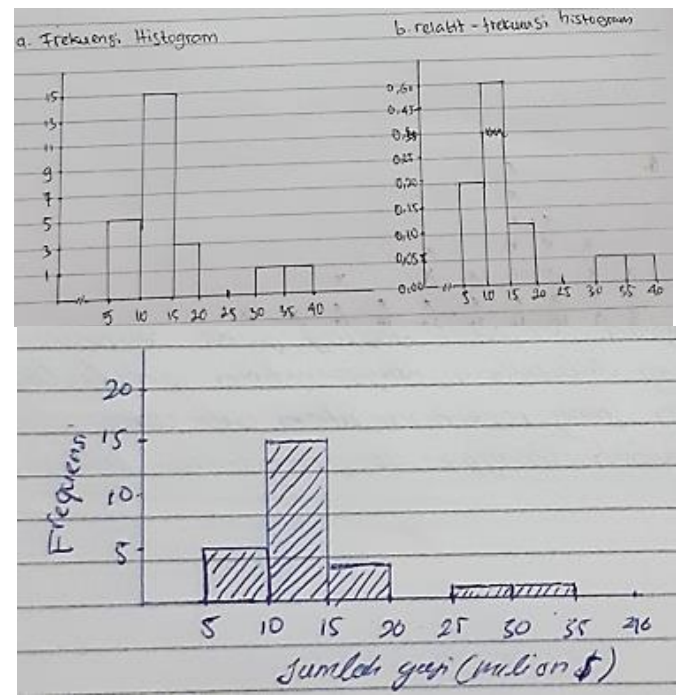

Gambar 8. Jawaban subjek mengenai penyajian data dalam bentuk histogram

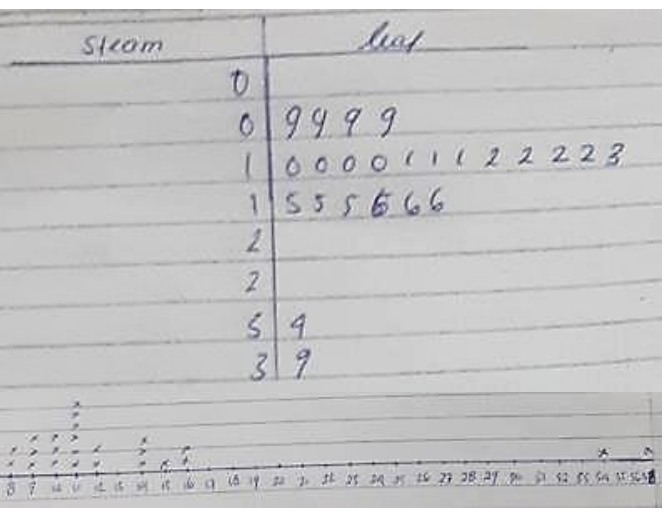

Gambar 9. Jawaban subjek mengenai penyajian data dalam bentuk steam and leaf plot dan dot plot 
nol, sehingga dari data ini frekuensinya naik kembali yang ditunjukkan pada batang keempat kemudian konstan pada batang kelima. Bentuk kurva dari gambaran sudut pandang semacam ini adalah kurva seperti pada gambar 10 .

Kurva inilah yang disebut sebagai kurva multimodal. Pemikiran berbeda terjadi pada subjek yang menganggap bawa bentuk distribusi data merupakan distribusi right skewed. Pada kasus subjek ini, diduga subjek memandang bagian kosong diantara batang ketiga dan keempat (lihat gambar 8) sebagai bagian yang tidak memiliki data, sehingga dari batang ketiga dapat langsung ditarik garis lurus ke batang keempat. Dalam kasus kedua ini, bentuk kurva yang terbentuk menyerupai lonceng yang tidak simetri dan landai di sebelah kanan (lihat gambar 10).

Berdasarkan cara pandang kedua kasus di atas, bentuk distribusi yang tepat adalah distribusi right skewed. Hal ini karena diantara batang ketiga dan keempat tidak ada data yang perlu dipertimbangkan, sehingga garis cukup langsung dibuat mengarah ke batang berikutnya.
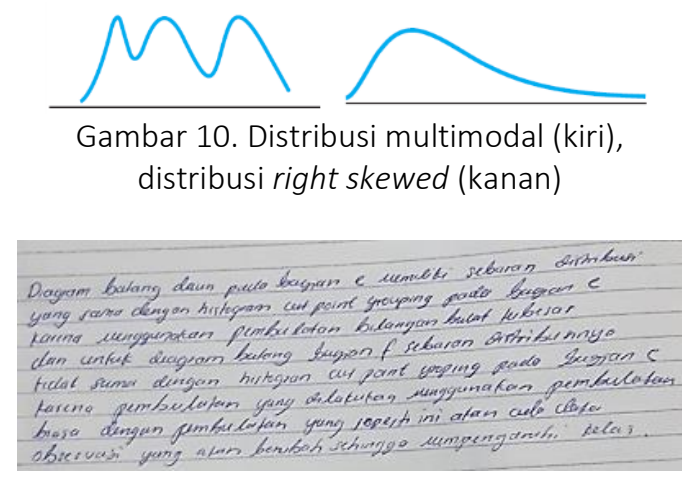

Gambar 11. Contoh penjabaran alasan subjek
Subjek juga memberikan alasan yang baik dalam menjelaskan mengapa sebaran data yang tersaji pada histogram sama dengan sebaran data pada steam and leaf plot. Selain keterampilan dalam menyajikan data, kemampuan yang tampak saat subjek menjelaskan alasannya (lihat gambar 11) adalah kemampuan untuk menunjukkan hubungan dari pemilihan teknik pembulatan bilangan dengan steam and leaf plot yang terbentuk dan efeknya terhadap hubungan antara bentuk distribusi data berdasarkan histogram dan steam and leaf plot. Oleh karena itu, penalaran statis yang muncul adalah penalaran proses terintegrasi.

Ringkasan mengenai kemampuan penalaran statistis subjek dalam menyelesaikan permasalahan kedua dapat dilihat pada tabel 3. Berbeda dengan tabel 1, Hasil pada tabel 2 menunjukkan bahwa penalaran statistis siswa meningkat dengan munculnya penalaran prosedural dan penalaran pengintegrasian proses.

$\mathrm{Hal}$ ini dimungkinkan terjadi mengingat

Tabel 3.

Penalaran Statistis pada Permasalahan 2

\begin{tabular}{|c|c|c|c|c|c|c|c|c|}
\hline Jenis Penalaran & a & $B$ & C & d & e & $f$ & $\mathrm{G}$ & $\mathrm{h}$ \\
\hline $\begin{array}{l}\text { Penalaran } \\
\text { Idiosinkratik }\end{array}$ & - & - & - & V & - & - & - & - \\
\hline $\begin{array}{l}\text { Penalaran } \\
\text { Verbal }\end{array}$ & $\sqrt{ }$ & - & - & V & - & - & - & - \\
\hline $\begin{array}{l}\text { Penalaran } \\
\text { Transisional }\end{array}$ & - & - & - & - & - & - & - & - \\
\hline $\begin{array}{l}\text { Penalaran } \\
\text { Prosedural }\end{array}$ & - & V & V & - & V & v & - & v \\
\hline $\begin{array}{l}\text { Penalaran } \\
\text { Pengintegrasian } \\
\text { Proses }\end{array}$ & - & - & - & - & - & - & V & - \\
\hline
\end{tabular}

Mosharafa: Jumal Pendidikan Matematika Volume 8, Nomor 2, Mei 2019 Copyright $\odot 2019$ Mosharafa: Jurnal Pendidikan Matematika 
pada permasalahan 2, soal lebih mengarah pada teknik atau cara tertentu yang dapat digunakan subjek dalam menyajikan data yang mereka miliki.

\section{Penutup}

Kemampuan penalaran statistis yang muncul sangat bergantung terhadap tujuan dari permasalahan yang diajukan. Apabila hanya tedapat level tertentu saja yang muncul, itu juga dimungkinkan karena permalahan yang diajukan menghendaki hal demikian.

\section{Daftar Pustaka}

Apriawan, D. C., Irham, I., \& Mulyo, J. H. (2014). Analisis produksi tebu dan gula di PT. Perkebunan Nusantara VII (PERSERO). Agro Ekonomi, 26(2), 159167.

Batanero, C., Godino, J. D., Vallecillos, A., Green, D. E., \& Holmes, P. (1994). Errors and difficulties in understanding elementary statistical concepts. International Journal of Mathematical Education in Science and Technology, 25(4), 527-547.

Ekayanti, A. (2017). Diagnosis Kesalahan Mahasiswa dalam Proses Pembuktian Berdasarkan Newmann Error Analysis. Mosharafa: Jurnal Pendidikan Matematika, 6(1), 105-116.

Febrilia, B. R. A. (2017). Pembelajaran distribusi Poisson dan penerapannya dalam kehidupan sehari-hari. Jurnal Didaktik Matematika, 4(1), 1-14.
Garfield, J. (2002). The challenge of developing statistical reasoning. Journal of Statistics Education, 10(3).

Garfield, J., \& Chance, B. (2000), Assessment in statistics education: issues and challenges. Mathematics Thinking and Learning , 2, 99-125.

Nisa, S., Zulkardi, Z., \& Susanti, E. (2019). Kemampuan penalaran statistis siswa pada materi penyajian data histogram melalui pembelajaran PMRI di SMANegeri 11 Palembang. Jurnal Pendidikan Matematika, 13(1), 21-40.

Manfaat, B., \& Nurhairiyah, S. (2013). Pengembangan instrumen tes untuk mengukur kemampuan penalaran statistik mahasiswa Tadris Matematika. Jurnal Jurusan Tadris Matematika, 2(02).

Maryati, I. (2017). Peningkatan kemampuan penalaran statistis siswa Sekolah Menengah Pertama melalui pembelajaran kontekstual. Mosharafa: Jurnal Pendidikan Matematika, 6(1), 129-140.

Mirawati, T. D., Yasin, H., \& Rusgiyono, A. (2013). Prediksi curah hujan di Kota Semarang dengan Metode Kalman Filter. In Prosiding Seminar Nasional Statistika Universitas Dipenogoro 2013 (pp. 561-570). Jurusan Statistika Undip.

Lestiani, M. E. (2018). Faktor-faktor dominan promosi yang mempengaruhi motivasi konsumen dalam membeli suatu produk dengan menggunakan metode Ahp. Jurnal 
Industri Elektro dan Penerbangan, $1(1)$.

Prabowo, A. (2013). Pembelajaran berbasis proyek untuk meningkatkan pemahaman mahasiswa atas permasalahan statistika pada perkuliahan studi kasus dan seminar. Kreano, Jurnal Matematika KreatifInovatif, 3(2), 82-90.

Rahman, A. A. (2018). Penerapan pendekatan Realistic Mathematic Education (RME) pada materi statistika untuk meningkatkan pemahaman konsep dan prestasi belajar siswa. Genta Mulia, 8(2).

Reading, C. (2002). Profile for statistical understanding. In Proceedings of the sixth international conference on teaching statistics, Cape Town, South Africa.

Setyorini, I. A., Pramudya, I., \& Setiawan, R. (2017). Analisis pemahaman konsep siswa terhadap materi pokok statistika ditinjau dari kebiasaan belajar matematika pada siswa kelas XII IPS 1 SMA Negeri 6 Surakarta tahun pelajaran 2016/2017. Jurnal Pendidikan Matematika dan Matematika SOLUSI, 1(4), 1-14.

Sholihah, S. Z., \& Afriansyah, E. A. (2017). Analisis Kesulitan Siswa dalam Proses Pemecahan Masalah Geometri Berdasarkan Tahapan Berpikir Van Hiele. Mosharafa: Jurnal Pendidikan Matematika, 6(2), 287-298.

Tresnawati, R., Nuraini, T. A., \& Hanggoro, W. (2010). Prediksi curah hujan bulanan menggunakan metode kalman filter dengan prediktor sst nino 3.4 diprediksi. Jurnal meteorologi dan geofisika, 11(2).

Ulpah, M. (2009). Belajar statistika: mengapa dan bagaimana?. Insania, 14(3), 325-435.

Ulpah, M., \& Kusumah, Y. S. (2012, November). Meningkatkan kemampuan penalaran statistis siswa Madrasah Aliyah melalui pembelajaran kontekstual. In Prosiding Seminar Nasional Matematika dan Pendidikan Matematika (pp. 563-570). Jurusan Pendidikan Matematika FPMIPA UNY

Weiss, N. A. (2011). Elementary statistics $8^{\text {th }}$ Edition. Boston, USA: Pearson Education, Inc.

Yulianingsih, A., Febrian, F., \& Dwinata, A. (2018). Analisa Kesalahan Konsep Pecahan pada Siswa Kelas VII A SMP Negeri 13 Satu Atap Tanjungpinang. Mosharafa: Jurnal Pendidikan Matematika, 7(2), 199-206.

Yusuf, Y. (2017). Konstruksi Penalaran Statistis pada Statistika Penelitian. Scholaria: Jurnal Pendidikan Dan Kebudayaan, 7(1), 60-69.

\section{Riwayat Hidup Penulis}

\section{Baiq Rika Ayu Febrilia, M.Si.}

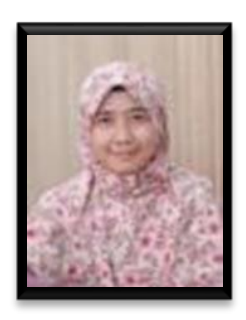

Lahir di Mataram, 7 Februari 1990. Staf pengajar di IKIP Mataram. Studi S1 Matematika Universitas Mataram, Kota Mataram, lulus tahun 2011 dan S2 Matematika ITB, Bandung, 2013. 